Pesq. Vet. Bras. 37(4):395-400, abril 2017 DOI: $10.1590 / \mathrm{S} 0100-736 \mathrm{X} 2017000400015$

\title{
Lipid content and cryotolerance of in vitro-produced bovine embryos treated with forskolin before vitrification ${ }^{1}$
}

\author{
Melissa Meneghel ${ }^{2,3}$, Priscila Chediek Dall'Acqua ${ }^{2,3}$, Marcela Ambrogi $^{2,3}$, \\ Beatriz C.S. Leão ${ }^{2,3}$, Nathália A.S. Rocha-Frigoni ${ }^{2,3}$ and Gisele Z. Mingoti ${ }^{2,3^{*}}$
}

\begin{abstract}
Meneghel M., Dall'Acqua P.C., Ambrogi M., Leão B.C.S., Rocha-Frigoni N.A.S. \& Mingoti G.Z. 2017. Lipid content and cryotolerance of in vitro-produced bovine embryos treated with forskolin before vitrification. Pesquisa Veterinária Brasileira 37(4):395400. Departamento de Apoio, Produção e Saúde Animal, Faculdade de Medicina Veterinária, Universidade Estadual Paulista, Rua Clóvis Pestana 793, Dona Amélia, Araçatuba, SP 16050-680, Brazil. E-mail: gmingoti@fmva.unesp.br

The aim of the present study was to evaluate the intracytoplasmic lipid content, development and cryotolerance of in vitro-produced bovine embryos treated with different concentrations of forskolin before vitrification. Embryos were produced from abattoir-derived ovaries and allocated into four groups. In the treatment groups, forskolin was added to the in vitro culture medium on Day 6 and incubated for 24 hours in one of the following concentrations: $2.5 \mu \mathrm{M}$ (Forsk 2.5 group), $5.0 \mu \mathrm{M}$ (Forsk 5.0 group) or $10.0 \mu \mathrm{M}$ (Forsk 10.0 group). Embryos from the control group were cultured without forskolin. On Day 7 of culture, the expanded blastocysts were stained with the lipophilic dye Sudan Black B for determination of the intracytoplasmic lipid content or were cryopreserved via the Vitri-Ingá ${ }^{\circledR}$ procedure. Although there were no significant differences $(\mathrm{P}>0.05)$ in the blastocyst rates between the Control group (44.9\%) and the other treatments, the embryo production was lower $(\mathrm{P}<0.05)$ in Forsk 10.0 group $(38.8 \%)$ compared to Forsk $2.5(50.5 \%)$ and Forsk 5.0 (54.7\%) groups. The intracytoplasmic lipid content (expressed in arbitrary units of pixels) in blastocysts from the Control group $(1.00 \pm 0.03)$ was similar $(\mathrm{P}>0.05)$ to that found in Forsk $2.5(0.92 \pm 0.03)$ and Forsk 10.0 groups $(1.06 \pm 0.03)$ groups; however the lipid accumulation in blastocysts from Forsk 5.0 group $(0.82 \pm 0.04)$ was lower than in the Control group $(\mathrm{P}<0.05)$. Based on these results, Forsk 5.0 treatment was tested for cryotolerance and it was observed that the blastocoel re-expansion rate evaluated 24 hours after warming was greater $(\mathrm{P}<0.05)$ in Forsk 5.0 group $(72.2 \%)$ compared to the Control group (46.2\%). In conclusion, pre-treatment with forskolin at a concentration of $5.0 \mu \mathrm{M}$ for 24 hours before vitrification is effective in reducing the intracytoplasmic lipid content and, consequently, improves cryotolerance of IVP bovine embryos.
\end{abstract}

INDEX TERMS: Lipid content, cryotolerance, forskolin, vitrification, in vitro production, embryo, bovine, intracytoplasmic lipid accumulation.

\footnotetext{
${ }^{1}$ Received on February 2, 2016.

Accepted for publication on August 11, 2016.

${ }^{2}$ Programa de Pós-Graduação em Medicina Veterinária (Reprodução Animal), Faculdade de Ciências Agrárias e Veterinárias, Universidade Estadual Paulista (Unesp), Via de Acesso Professor Paulo Donato Castellane s/n, Jaboticabal, SP 14884-900, Brazil. E-mails: melissameneghel@ hotmail.com, prichediek@hotmail.com, marcelaambrogi9@gmail.com, naniasrocha@hotmail.com, beatriz_csl@yahoo.com.br

${ }^{3}$ Departamento de Apoio, Produção e Saúde Animal, Faculdade de Medicina Veterinária, Unesp, Rua Clóvis Pestana 793, Dona Amélia, Araçatuba, SP 16050-680, Brazil. *Corresponding author: gmingoti@fmva.unesp.br
}

RESUMO.- [Acúmulo de lipídios intracitoplasmáticos, desenvolvimento e criotolerância de embriões bovinos produzidos in vitro e tratados com diferentes concentrações de forskolin antes da vitrificação.] Os embriões foram produzidos a partir de ovários obtidos em abatedouro e foram alocados em quatro grupos experimentais. Nos grupos tratados, o forskolin foi adicionado ao meio de cultivo in vitro no dia 6 do cultivo e os embriões foram incubados durante 24 horas com uma das seguintes concentra-

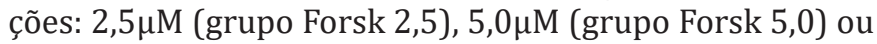


10,0 $\mathrm{MM}$ (grupo Forsk 10,0). Os embriões do grupo controle foram cultivados na ausência de forskolin. No dia 7 do cultivo, os blastocistos expandidos foram corados com o corante lipofílico Sudan Black B para a determinação do teor de lípidos intracitoplasmáticos ou foram criopreservados através do protocolo Vitri-Ingá ${ }^{\circledR}$. Não foi observada diferença significativa $(\mathrm{P}>0,05)$ na taxa de produção de blastocistos entre o grupo Controle $(44,9 \%)$ e os demais tratamentos, todavia observou-se menor produção de embriões $(\mathrm{P}<0,05)$ no grupo Forsk $10,0(38,8 \%)$ em comparação com os grupos Forsk 2,5 (50,5\%) e Forsk 5,0 (54,7\%). A quantidade de lipídeos intracitoplasmáticos do grupo Controle $(1,00 \pm 0,03)$ foi semelhante $(\mathrm{P}>0,05)$ a dos grupos Forsk 2,5 $(0,92 \pm 0,03)$ e Forsk $10,0(1,06 \pm 0,03)$; no entanto, o acúmulo de lípidos nos blastocistos do grupo Forsk $5.0(0,82 \pm$ $0,04)$ foi menor do que no grupo controle $(\mathrm{P}<0,05)$. A partir destes resultados, o grupo Forsk 5,0 foi testado quanto à criotolerância e foi observado que a taxa de re-expansão da blastocele 24 horas após o aquecimento foi maior $(\mathrm{P}<0,05)$ no grupo Forsk 5,0 (72,2\%) quando comparado ao grupo Controle (46,2\%). Em conclusão, o pré-tratamento com forskolin na concentração de 5,0 $\mu \mathrm{M}$ durante 24 horas antes da vitrificação foi eficiente para promover a redução da quantidade de lipídeos intracitoplasmáticos e, consequentemente, melhorou a criotolerância de embriões bovinos produzidos in vitro.

TERMOS DE INDEXAÇÃO: Lipídios intracitoplasmáticos, criotolerância, forskolin, vitrificação, produção in vitro, embrião, bovino, acúmulo lipídico intracitoplasmático.

\section{INTRODUCTION}

In the last decades, the introduction of innovating reproductive biotechnologies in agriculture allowed this field to grow significantly and increased the efficiency and profitability of livestock (Blondin 2015). Currently, the global production of bovine embryos produced in vitro (IVP) exceeded the half million mark, with a total of 517,587 embryos produced from oocytes recovered from females by transvaginal ovum pick-up (OPU). Of this total of IVP embryos, $70.8 \%$ were produced in Brazil and most of them were freshly transferred $(301,552$ embryos were transferred in 2013, of which 95\% were fresh and 5\% were frozen) (Perry 2015).

On the other hand, embryos produced in vivo are less sensitive to cryopreservation than those produced in vitro (Abe et al., 2002, Rizos et al. 2003, Pereira et al. 2008). Currently, the cryopreservation of in vivo-produced embryos is routinely used in commercial programs of embryo transfer (ET). According to the International Embryo Transfer Society (IETS), in 2013 almost $60 \%$ of transfers of in vivo-derived bovine embryos were carried out after thawing of cryopreserved embryos (Perry 2015). Thus, cryopreservation of embryos is a key tool for storage and exchange of genetic resources of farm animals (Almiñana \& Cuello 2015).

The reduced resistance of IVP embryos to cryopreservation (Abe et al. 2002, Rizos et al. 2003, Pereira et al. 2008) can be partially attributed to the effects of some components of the in vitro culture (IVC) medium, especially fetal cow serum (FCS). The FCS may interfere with embryonic lipid metabolism in three different ways: increasing the synthesis of lipids (especially triacylglycerides) in embryos (Abd El Razek et al. 2000); increasing the lipid content via internalization of lipoproteins present in serum (Ferguson \& Leese 1999, Sata et al. 1999); or altering lipid metabolism in the mitochondria, mainly by increasing the intracellular lipid stocks (Abe \& Hoshi 2003). The large amount of lipid droplets in the cytoplasm of in vitro produced embryos, especially in the early stages of development, makes the embryos more sensitive to chilling injuries (Almiñana \& Cuello 2015).

To overcome the problem of excessive lipid accumulation and thus improve the embryo survival after cryopreservation, two strategies can be pursued: developing better cryopreservation techniques or modifying the molecular composition of the embryos during IVC to render them more cryotolerant (Massip et al. 1995, Seidel 2006, Gómez et al. 2008). In this regard, some strategies have been initially proposed to prevent the excessive lipid accumulation in the in vitro-produced embryos, such as mechanical removal of lipids before cryopreservation (Nagashima et al. 1995). However, this invasive method changes the developmental potential of blastocysts transferred to recipients (Diez et al. 2001). Moreover, the mechanical delipidation substantially increases the chance of transmission of pathogens because of the zona pellucida damage induced by micromanipulation (Stringfellow 1998).

A partial delipidation induced by chemical agents has been proposed as a more appropriate strategy. Several drugs have lipolytic effect, including norepinhephrine, dibutyryl cyclic adenosine monophosphate (dbcMP), isoproterenol, forskolin and theophyline. Forskolin has been reported to increase the cryosurvival of porcine blastocysts produced in vitro by reducing their intracellular lipid content, especially triacylglycerols (Men et al. 2006). Although data concerning the effect of forskolin on bovine IVP embryos are more scarce than for pig, recent studies demonstrated an improvement in bovine embryo survival and quality after vitrification (Paschoal et al. 2012, Sanches et al. 2013).

Forskolin acts by activating the adenylate cyclase that regulates cyclic adenosine monophosphate (cAMP) levels in cells (Seamon et al. 1981, Ho \& Shi 1982, Ek et al. 1997, Arrese et al. 1999). CAMP is an important signaling molecule that regulates the physiological functions of various systems (Seamon et al. 1981, Ho \& Shi 1982, Ek et al. 1997, Arrese et al. 1999), including the regulation of lipolysis (Lafontan \& Berlan 1993). Although the delipidation induced by forskolin have improved cryotolerance of bovine embryos (Paschoal et al. 2012, Sanches et al. 2013), the effects of increasing cAMP levels are unspecific on the metabolism (Seamon et al. 1981, Ho \& Shi 1982, Ek et al. 1997, Arrese et al. 1999), so it is possible that forskolin can induce effects on embryonic cells that are still unknown (Sanches et al. 2013). For this reason, it is necessary to establish the lowest effective dose of this drug for purpose of inducing lipolysis in IVP embryos.

Therefore, the aim of this study was to evaluate the 
effects of different concentrations of forskolin added during in vitro culture on the total amount of intracellular lipids and cryotolerance of IVP bovine embryos after vitrification.

\section{MATERIALS AND METHODS}

Chemicals, reagents and media. Chemicals were purchased from Sigma Chemical Co. (St Louis, MO, USA) unless otherwise stated. Plastic materials were obtained from Corning Inc. (Acton, MA, USA). The medium for in vitro maturation (IVM) consisted of TCM199 (Gibco $^{\circledR}$, Invitrogen Co., Grand Island, NY, USA) supplemented with $10 \%$ (v:v) FCS (Gibco ${ }^{\circledR}$, Invitrogen Co.), $0.2 \mathrm{mM}$ sodium pyruvate, $25 \mathrm{mM}$ sodium bicarbonate, $50 \mu \mathrm{g} / \mathrm{mL}$ amikacin, $0.5 \mu \mathrm{g} / \mathrm{mL}$ FSH (Folltropin-V, Bioniche Animal Health, Ontario, Canada), and $100 \mathrm{IU} / \mathrm{mL}$ hCG $\left(\right.$ Vetecor $^{\circledR}$, Hertape Calier, Juatuba, MG, Brazil). The medium for in vitro fertilization (IVF) consisted of Tyrode's albumin lactate pyruvate (TALP) containing $0.2 \mathrm{mM} \mathrm{Na-}$ -pyruvate, $6 \mathrm{mg} / \mathrm{mL}$ fraction $\mathrm{V}$ fatty acid-free bovine serum albumin (BSA), $25 \mathrm{mM}$ sodium bicarbonate, $13 \mathrm{mM}$ Na-lactate, $50 \mu \mathrm{g} /$ $\mathrm{mL}$ amikacin, $40 \mu \mathrm{L} / \mathrm{mL}$ PHE solution (1mM hypotaurine, $2 \mathrm{mM}$ penicillamine and $250 \mu \mathrm{M}$ epinephrine) and $10 \mu \mathrm{g} / \mathrm{mL}$ heparin, as previously described (Parrish et al. 1988). The medium for IVC of embryos consisted of modified synthetic oviductal fluid (SOF), as previously described (Vajta et al. 1999), supplemented with $50 \mu \mathrm{g} / \mathrm{mL}$ amikacin, $5 \mathrm{mg} / \mathrm{mL}$ BSA and $2.5 \%$ (v:v) FCS. Milimolar stock concentrations of forskolin were stored at $20^{\circ} \mathrm{C}$ dissolved in anydrous dimethylsulphoxide (DMSO) solutions and were freshly diluted each day of the experiment to obtain a final concentration of $10 \mu \mathrm{M}, 5 \mu \mathrm{M}$ and $2.5 \mu \mathrm{M}$. The maximum final concentration of DMSO in the cultures was $0.08 \%$ (according to previous results from Stinshoff et al. (2014), the presence of 0.2\% DMSO in the culture medium exerted no toxic effects on the developing embryos compared to control).

Oocyte collection and maturation. Ovaries from slaughtered cows were obtained in a local abattoir and transported to the laboratory. Intact cumulus-oocyte complexes (COCs) were aspirated from antral follicles ( 3 to $8 \mathrm{~mm}$ in diameter), and oocytes with at least four layers of cumulus cells with homogenous cytoplasm were selected for the experiments. Selected COCs $(n=848)$ were washed and cultured in microdrops of $100 \mu \mathrm{L}$ of IVM medium (20 oocytes/microdrop), covered with mineral oil for 22 hours at $38.5^{\circ} \mathrm{C}$ in an atmosphere of $5 \% \mathrm{CO}_{2}$ in air with maximum humidity.

In vitro fertilization. Following IVM, oocytes were subjected to fertilization with frozen semen from a single batch from a Nellore bull (Bos taurus indicus). Motile spermatozoa were obtained by centrifugation of the frozen-thawed semen on a Percoll (GE Healthcare, Uppsala, Sweden) discontinuous density gradient $(250 \mu \mathrm{L}$ of $45 \%$ Percoll over $250 \mu \mathrm{L}$ of $90 \%$ Percoll in a $1.5 \mathrm{~mL} \mathrm{mi}-$ crotube) for $7 \mathrm{~min}$ at $2500 \times g$ at room temperature. Sperm cells were added to the fertilization droplet at $2 \times 10^{6}$ cells $/ \mathrm{mL}$. The COCs ( 20 per $90 \mu \mathrm{L}$ droplet overlaid with mineral oil) and spermatozoa were coincubated for 18 hours at $38.5^{\circ} \mathrm{C}$ in an atmosphere of $5 \% \mathrm{CO}_{2}$ in air, with maximum humidity. The day of fertilization was defined as Day 0 (D0).

Embryo culture. Following fertilization, the presumptive zygotes were partially stripped from the cumulus cells by gentle pipetting and subsequently washed three times in TALP medium and twice in IVC medium. Zygotes were cultured in $500 \mu \mathrm{L}$ of IVC medium (control group), supplemented on D6 with forskolin in one of the following concentrations: (A) $2.5 \mu \mathrm{M}$ (group Forsk 2.5); (B) $5 \mu \mathrm{M}$ (group Forsk 5.0); or (C) $10.0 \mu \mathrm{M}$ (group Forsk 10.0). Embryos were cultured without mineral oil (20 embryos per well) on a monolayer of cumulus cells in a 4 -well cell culture plate. The culture was carried out at $38.5^{\circ} \mathrm{C}$ in an atmosphere of $5 \% \mathrm{CO}_{2}$ in air, with maximum humidity. Cleavage rates were assessed under stereoscopic microscopy at $40 \times$ magnification at 72 hours post-insemination (h.p.i.), and blastocyst development rates were recorded at 168 h.p.i. (Day 7).

Quantification of intracellular lipid content by Sudan Black B staining. The intracellular lipid content in D7-expanded blastocysts $(n=99)$ was quantified using the lipophilic dye Sudan Black B. Embryos were fixed in $1 \mathrm{ml} 4 \%$ paraformaldehyde in PBS, $\mathrm{pH} 7.4$, for 2 hours at room temperature. Then, they were washed in PBS containing 0.5\% PVP and then transferred to drops of $50 \%$ ethanol in distilled water. After $2 \mathrm{~min}$, embryos were stained in drops of $1 \%$ Sudan Black B (w/v) in $70 \%$ ethanol for 2 min, then they were washed 3 times with $50 \%$ ethanol, 5 min each, followed by a 5 min wash in $0.5 \%$ PVP in distilled water. Prepared embryos were mounted in $10-\mu \mathrm{L}$ drop of glycerol on cover slips and examined under a light microscope at at $40 \times$ magnification. Stained embryos were imaged immediately using an Olympus, IX51 inverted microscope running image Q-Capture Pro Image software (Media Cybernetics, Inc., Version 5.0.1.26) to quantify the area and intensity of pixels from embryos. Images were converted to gray scale and the background signal intensity was subtracted from the measured values of the treatment micrographs. The control group was chosen as a calibrator and the measured value of each treatment micrograph was divided by the mean of the calibrator to generate the relative expression levels of pixels (expressed in arbitrary units). The means of the relative expression values were plotted graphically with error bars representing the standard error of the mean (SEM).

Vitrification, warming and subsequent embryo culture. All materials used for the vitrification-warming procedures were supplied by Ingámed (Perobal, Brazil), including the vitrification solutions (VI-I and VI-II), warming solutions (DV-I, DV-II and DV-III), vitrification strips (Vitri-Ingá) and their plastic sheaths. Expanded blastocysts (grades 1 and 2, classified according to the IETS Manual (Wright, 2009) were washed twice in holding medium (SOF supplemented with $250 \mathrm{mM} \mathrm{HEPES}$ and $20 \%$ of FCS) and transferred to VI-I for $5 \mathrm{~min}$ at $37^{\circ} \mathrm{C}$. Subsequently, the embryos were transferred to a $10-\mu \mathrm{L}$ drop of VI-II for 60 s at room temperature. Then, the embryos were placed in the hole in the tip of a Vitri-Ingá strip with a minimum amount of vitrification solution and immersed directly in liquid nitrogen $\left(\mathrm{N}_{2}\right)$. The plastic sheaths, that had been cooled previously in $\mathrm{N}_{2}$ liquid vapour for 1 min, were immersed vertically in the liquid $\mathrm{N}_{2}$. The Vitri-Ingá strips were then inserted into the plastic sheaths for safe storage. For the warming procedure, the Vitri-Ingá strips were withdrawn from the liquid $\mathrm{N}_{2}$ and transferred to the DV-I warming solution for $1 \mathrm{~min}$ at $37^{\circ} \mathrm{C}$. Subsequently, embryos were transferred to DVII for $3 \mathrm{~min}$ at room temperature and washed twice in DV-III for 5 min each time. The embryos were next washed twice in holding medium and cultured in SOF supplemented with $2.5 \%$ (v:v) FCS and $5 \mathrm{mg} / \mathrm{mL} \mathrm{BSA}$ under saturated humidity and $5 \% \mathrm{CO}_{2}$ for 24 hours. Thereafter, embryos were evaluated to determine the blastocoel re-expansion rates.

Statistical analysis. The experiments were replicated at least four times, on different days. The percentage of embryos at specific stages of development was estimated by considering the total number of oocytes in each maturation well. Blastocysts rates and re-expansion frequency were analysed with a Chi-squared test. Intracellular lipid content was compared by ANOVA. When a statistically significant effect was found, Tukey's test was applied for multiple comparisons of means. The data were analyzed using JMP statistical software version 5.0.1a (SAS Inst. Inc., Cary, NC, USA). The level of statistical significance was set at $\mathrm{P}<0.05$. 


\section{RESULTS}

The effects of different concentrations of forskolin during IVC on cleavage and blastocyst rates are given in Table 1. There was no effect $(\mathrm{P}>0.05)$ of forskolin on cleavage rates (mean 81.7\%). Embryo development to the blastocyst stage was higher $(\mathrm{P}<0.05)$ when forskolin was added to IVC medium at $2.5 \mu \mathrm{M}(50.5 \%)$ and $5.0 \mu \mathrm{M}(54.7 \%)$ than at $10.0 \mu \mathrm{M}(38.8 \%)$. However, none of these treatments differ $(\mathrm{P}>0.05)$ from the control group (44.9\%).

Intracellular lipid content of expanded blastocysts (expressed as expressed in arbitrary units of pixels; Fig.1) was similar $(\mathrm{P}>0.05)$ between the control group $(1.00 \pm 0.03)$ and Forsk $2.5(0.92 \pm 0.03)$ and Forsk 10.0 (1.06 \pm 0.03$)$ groups. However, the intracellular lipid content was decreased $(\mathrm{P}<0.05)$ in Forsk 5.0 group $(0.82 \pm 0.04)$ compared

Table 1. Cleavage and embryonic development to the blastocyst stage of bovine embryos cultured in vitro in the presence of different concentrations of forskolin

\begin{tabular}{lccc}
\hline Groups & Oocytes (n) & Cleavage n (\%) & Blastocysts n (\%) \\
\hline Control & 198 & $160(80.8)$ & $89(44.9)^{\mathrm{ab}}$ \\
Forsk 2.5 & 194 & $160(82.5)$ & $98(50.5)^{\mathrm{a}}$ \\
Forsk 5.0 & 192 & $160(83.3)$ & $105(54.7)^{\mathrm{a}}$ \\
Forsk 10.0 & 188 & $151(80.3)$ & $73(38.8)^{\mathrm{b}}$
\end{tabular}

Control: embryos were cultured in vitro in IVC medium (SOF suplemented with $2.5 \%$ SFB and 2.5\% BSA); Forsk 2.5: embryos were cultured in vitro in IVC medium suplemented with $2.5 \mu \mathrm{M}$ forskolin from the 6th day (D6) to the end of the culture (D7); Forsk 5.0: embryos were cultured in vitro in IVC medium suplemented with $5.0 \mu \mathrm{M}$ forskolin from D6 to D7; Forsk 10.0: embryos were cultured in vitro in IVC medium suplemented with $10.0 \mu \mathrm{M}$ forskolin from D6 to D7. Treatments were repeated in four replicates. ${ }^{\text {ab }}$ ifferent letters indicate significant differences between treatments $(\mathrm{P}<0.05$, Chi-squared test $)$.

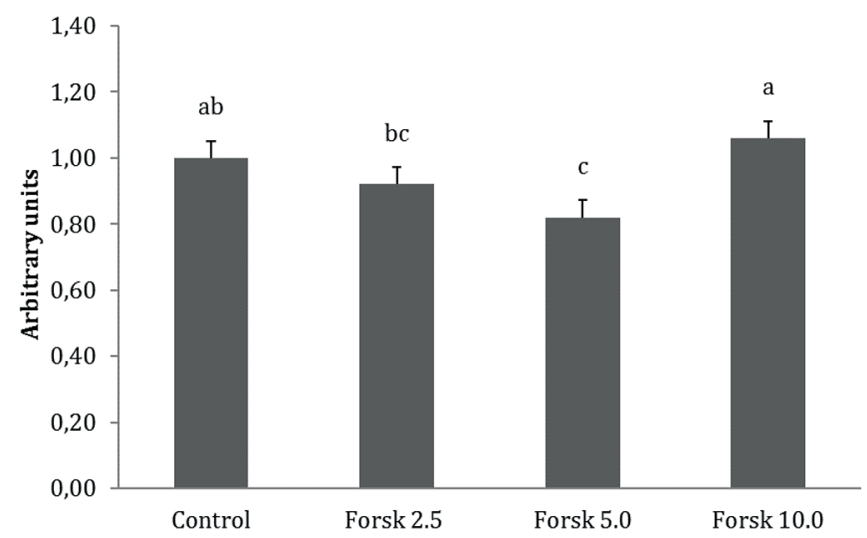

Fig.1. Effect of forskolin supplementation during in vitro culture on intracellular lipid content of expanded blastocysts. Control: embryos $(n=31)$ were cultured in vitro in IVC medium (SOF suplemented with 2.5\% SFB and 2.5\% BSA); Forsk 2.5: embryos $(n=23)$ were cultured in vitro in IVC medium suplemented with $2.5 \mu \mathrm{M}$ forskolin from the 6th day (D6) to the end of the culture (D7); Forsk 5.0: embryos $(n=22)$ were cultured in vitro in IVC medium suplemented with $5.0 \mu \mathrm{M}$ forskolin from D6 to D7; Forsk 10.0: embryos $(n=23)$ were cultured in vitro in IVC medium suplemented with $10.0 \mu \mathrm{M}$ forskolin from D6 to D7. Treatments were repeated in four replicates. The data represent the mean \pm SEM. ${ }^{\text {abc }}$ Different letters indicate significant differences between treatments $(\mathrm{P}<0.05$, Tukey's test).
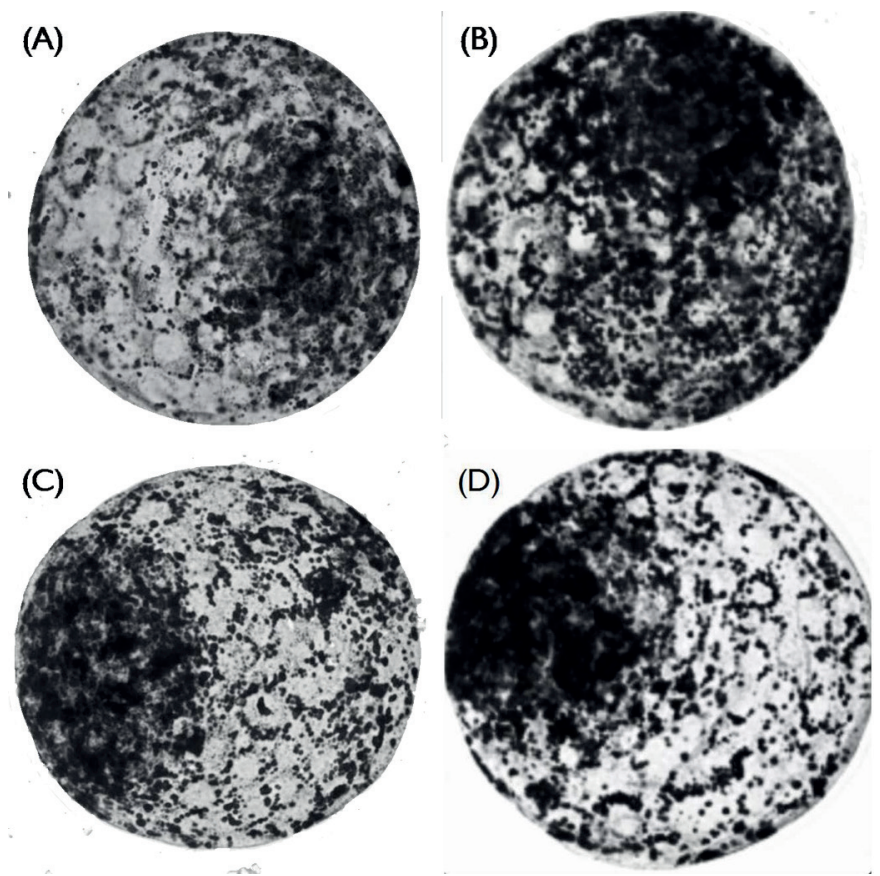

Fig.2. Representative photomicrographs of bovine embryos stained with Sudan Black B for evaluation of intracellular li-

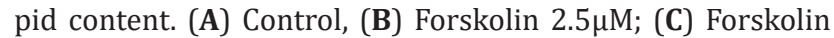
$5.0 \mu \mathrm{M}$, and (D) Forskolin $10.0 \mu \mathrm{M}, 40 \times$ magnification. Images converted to gray scale.

Table 2. Effects of forskolin during in vitro culture on the blastocoel re-expansion rates of vitrified-warmed expanded blastocysts

\begin{tabular}{lccc}
\hline Groups & $\begin{array}{c}\text { Embryos } \\
(\mathrm{n})\end{array}$ & $\begin{array}{c}\text { Immediate re-expansion } \\
\text { (0 hours) } \mathrm{n}(\%)\end{array}$ & $\begin{array}{c}\text { Re-expansion 24 hours } \\
\text { after warming } \mathrm{n}(\%)\end{array}$ \\
\hline Control & 39 & $12(30,8)$ & $18(46,2)^{\mathrm{a}}$ \\
Forsk 5.0 & 35 & $14(40,0)$ & $25(71,4)^{\mathrm{b}}$
\end{tabular}

Control: embryos were cultured in vitro in IVC medium (SOF suplemented with $2.5 \%$ SFB and $2.5 \%$ BSA); Forsk 5.0: embryos were cultured in vitro in IVC medium suplemented with $5.0 \mu \mathrm{M}$ forskolin from the 6th day (D6) to the end of the culture (D7). Treatments were repeated in five replicates. ${ }^{a b}$ Different letters in the column indicate significant differences between treatments $(\mathrm{P}<0.05$, Chi-squared test).

to the others. Representative photomicrographs of bovine embryos stained with Sudan Black B are shown in Figure 2.

As the treatment with $5.0 \mu \mathrm{M}$ forskolin was more effective to reduce the lipid content in the embryos, this group was tested for cryotolerance. It was observed that the re-expansion rates evaluated after 24 hours of in vitro culture was higher $(\mathrm{P}<0.05)$ in Forsk 5.0 group $(71.4 \%)$ compared to control group (46.2\%). This results are given in Table 2 .

\section{DISCUSSION}

There is growing evidence suggesting that the intrinsic quality of the oocyte is the key factor in determining the proportion of oocytes that develop to the blastocyst stage (Rizos et al. 2003, Lonergan et al. 2003). In this study, only oocytes of best quality (according to International Embryo Transfer Society standards) were selected for the experiments, and how the treatments were performed only in 
the embryos but not in the oocytes, it was expected that the blastocyst yields were unaffected by supplementation of IVC medium with forskolin in various concentrations. These results are in agreement with data from Paschoal et al. (2012), which did not observe differences in blastocyst yield of embryos treated with $(46.3 \%$ and $34.2 \%$ in medium supplemented with or without FCS, respectively) or without $10 \mu \mathrm{M}$ forskolin $(46.8 \%$ and $33.3 \%$ in medium supplemented with or without FCS, respectively) during 24 hours of IVC. Likewise, Sanches et al. (2013) found no differences in blastocysts production rates after treatment of IVC embryos with $10 \mu \mathrm{M}$ forskolin for 48 hours (45.3\%) compared to untreated embryos (39.9\%).

On the other hand, growing evidence indicates that the post-fertilization culture environment, rather than the origin of the oocytes, is the main factor determining blastocyst quality (Rizos et al. 2003, Lonergan et al. 2003). Although the addition of forskolin did not affect embryonic development rates in the present study, the intracellular lipid content was lowered and, consequently, the cryoresistence was increased in embryos treated with $5.0 \mu \mathrm{M}$ forskolin during 24 hours before vitrification. Such observations highlight the importance of the post-fertilization culture environment for the quality of the resulting blastocyst. Although the term "quality" is very unspecific and the parameters that allow the classification of embryos in different quality grades were not well established until the present time, several studies have evaluated the quality in terms of specifics aspects like apoptosis rates, cytoplasmic accumulation of reactive oxygen species, mitochondrial membrane potential, lipid accumulation, resistance to freezing and even pregnancy rates after transfer to synchronized recipients (Accorsi et al. 2016, Rocha-Frigoni et al. 2014, Sanches et al. 2013, Paschoal et al. 2012, Pereira et al. 2008). Thus, the present results demonstrated an increase in the quality of in vitro-produced bovine embryos treated with forskolin, measured in terms of cryotolerance.

The addition of FCS in the culture medium is one of the main factors responsible for causing morphological and physiological differences (Abe et al. 1999, Pereira et al. 2008) in IVC embryos when compared to embryos produced in the absence of FCS (Rizos et al. 2003) or embryos produced in vivo (Paschoal et al. 2012). Some of these differences include the increased number and size of lipid droplets (Abe et al. 1999, Rizos et al. 2003) and differences in the viability of embryos, evaluated by the percentage of damaged cells (Paschoal et al. 2012.). To avoid the undesirable intracellular accumulation of lipids, several studies have tried to replace serum in the culture medium (Mingoti et al. 2009). However, despite their potential adverse effects on embryo quality (Rizos et al. 2003), the serum contains substances which are beneficial to the embryo development, such as growth factors and chelators of heavy metals (Stein 2007). For this reason, it has been difficult to avoid or find a suitable replacement for serum in media formulated for in vitro cultures, particularly for laboratories working with commercial purpose.

As the lipid accumulation has often been associated with loss of embryo viability and the increase in injuries caused by cryopreservation, this study investigated the effect of chemical lipolysis with the use of various concentrations of forskolin in an attempt to find the lower efficient concentration able to reduce the intracellular lipid accumulation in embryos produced in vitro in the presence of FCS, and results demonstrated a significant reduction in the cytoplasmic lipid content at the dose of $5.0 \mu \mathrm{M}$ forskolin. Although previous studies have been developed to evaluate the lipolytic effects of forskolin in bovine IVC embryos, it is not yet established the best protocol, including the most effective dose and duration of treatment. In a preliminary communication, Paschoal et al. (2015) found effective lipolytic activity when treating bovine embryos with low doses of forskolin (lipid measurement in control: 50.6 vs $2.5 \mu \mathrm{M}$ forskolin: 46.2 ), however these authors did not evaluate whether this low concentration of forskolin improved embryo quality in terms of cryotolerance. Paschoal et al. (2012) found similar re-expansion rates after warming of vitrified in vivo-derived embryos and embryos produced in vitro in the presence of forskolin at a dose of $10.0 \mu \mathrm{M}$ for 24 hours. Likewise, Sanches et al. (2013) found no differences in the rates of blastocoel re-expansion and hatching of embryos exposed to $10.0 \mu \mathrm{M}$ forskolin for 48 hours before vitrification ( $87.5 \%$ and $70.5 \%$, respectively) compared with non-treated embryos $(79.2 \%$ and $63.3 \%$, respectively). Thus, the condition established in the present study (dose of $5.0 \mu \mathrm{M}$ forskolin for 24 hours before vitrification) seems to be more effective than those proposed in earlier studies.

As previously mentioned, the reduction of the effective dose of forskolin is desirable because this drug stimulates lipolysis via activation of adenylate cyclase with consequent increase in cAMP levels (Honnor et al. 1985, Lafontan \& Berlan 1993). Since the effects of cAMP are unspecific, as this signaling molecule regulates several physiological functions (Seamon et al. 1981, Ho \& Shi 1982, Ek et al. 1997, Arrese et al. 1999), it is possible that forskolin can induce effects on embryonic cells that are still unknown (Sanches et al. 2013). When compared to previous studies (Sanches et al. 2013, Paschoal et al. 2012), the results of the present study demonstrated that lower concentrations of forskolin was still effective in induction of cellular lipolysis, but more studies are needed in order to assess the effects of this drug on the metabolism, gene expression and embryonic proteome. However, as expected, the use of forskolin improved embryo survival after vitrification-warming as a result of reduction of intracytoplasmic lipid content. These findings confirm that the use of lipolytic agents is a valuable strategy to improve the quality of bovine embryos produced in vitro, aiming to produce blastocysts with higher rates of post-cryopreservation survival.

\section{CONCLUSION}

In conclusion, pre-treatment with 5.0uM forskolin for 24 hours before vitrification decreases the intracytoplasmic lipid content and improves the cryotolerance of IVP bovine embryos.

Acknowledgements.- Fapesp (\#2013/07382-6), CAPES and CNPq (\#306746/2012-3). 


\section{REFERENCES}

Abd El Razek I.M., Charpigny G., Kodja S., Marquant-Leguienne B., Mermillod P. \& Guyader-Joly C. 2000. Differences in lipids composition between in vivo and in vitro produced bovine embryos. Theriogenology 53:1219.

Abe H. \& Hoshi H. 2003. Evaluation of bovine embryos produced in high performance serum-free media. J. Reprod. Develop. 49:193-202.

Abe H., Yamashita S., Itoh T., Satoh T. \& Hoshi H. 1999. Ultrastructure of bovine embryos developed from in vitro-matured and -fertilized oocytes: comparative morphological evaluation of embryos cultured either in serum-free medium or in serum-supplemented medium. Mol. Reprod. Dev. 53:325-335.

Abe H., Yamashita S., Satoh T. \& Hoshi H. 2002. Accumulation of cytoplasmic lipid droplets in bovine embryos and cryotolerance of embryos developed in different culture systems using serum-free or serum containing media. Molec. Reprod. Develop. 61:57-66.

Accorsi M.F., Leão B.C.S., Rocha-Frigoni N.A.S., Perri S.H.V. \& Mingoti G.Z. 2016. Reduction in cytoplasmic lipid content in bovine embryos cultured in vitro with linoleic acid in semi-defined medium is correlated with increases in cryotolerance. Zygote 24(4):485-494.

Almiñana C. \& Cuello C. 2015. What is new in the cryopreservation of embryos? Anim. Reprod. 12(3):418-427.

Arrese E.L., Matthew T.F., Gazard J.L. \& Wells M.A. 1999. Calcium and cAMP are second messengers in the adipokinetic hormone-induced lipolysis of triacylglycerols in Manduca sexta fat body. J. Lip. Res. 40:556-64.

Blondin P. 2015. Status of embryo production in the world. Anim. Reprod. 12(3):356-358.

Diez C., Heyman Y., Le Bourhis D., Guyader-Joly C., Degrouard J. \& Renard J.P. 2001. Delipidating in vitro-produced bovine zygotes: effect on further development and consequences for freezability. Theriogenology 55:923-936.

Ek I., Arner P., Bergqvist A., Carlström K. \& Wahrenberg H. 1997. Impaired adipocyte lipolysis in nonobese women with the polycystic ovary syndrome: a possible link to insulin resistance? J. Clin. Endocrinol. Metabol. 82:1147-1153.

Ferguson E.M. \& Leese H.J. 1999. Triglyceride content of bovine oocytes and early embryos. J. Reprod. Fert. 116:373-378.

Gómez E., Rodríguez A., Muñoz M., Caamaño J.N., Hidalgo C.O., Morán E., Facal N. \& Díez C. 2008. Serum free embryo culture medium improves in vitro survival of bovine blastocysts to vitrification. Theriogenology 69:1013 1021.

Ho R.J. \& Shi Q.H. 1982. Forskolin as a novel lipolytic agent. Biochem. Biophys. Res. Commun. 107:157-164.

Honnor R.C., Dhillon G.S. \& Londos C. 1985. cAMP-dependent protein kinase and lipolysis in rat adipocytes. II. Definition of steadystate relationship with lipolytic and antilipolytic modulators. J. Biol. Chem. 260:15130-15138.

Lafontan M. \& Berlan M. 1993. Fat cell adrenergic receptors and the control of white and brown fat cell function. J. Lip. Res. 34:1057-1091.

Lonergan P., Rizos D., Gutierrez-Adan A., Fair T. \& Boland M.P. 2003. Oocyte and embryo quality: effect of origin, culture conditions and gene expression patterns. Reprod. Dom. Anim. 38:259-267.

Massip A., Mermillod P. \& Dinnyes A. 1995. Morphology and biochemistry of in vitro produced bovine embryos: implications for their cryopreservation. Hum. Reprod. 10(11):3004-3011.

Men H., Agca Y., Riley L.K. \& Critser J.K. 2006. Improved survival of vitrified porcine embryos after partial delipation through chemically stimulated lipolysis and inhibition of apoptosis. Theriogenology 66:2008-2016.

Mingoti G.Z., Caiado Castro V.S., Méo S.C., Barretto L.S. \& Garcia J.M. 2009.
The effect of interaction between macromolecule supplement and oxygen tension on bovine oocytes and embryos cultured in vitro. Zygote 17:321-382.

Nagashima H., Kashiwazaki N., Ashman R.J., Grupen C.G. \& Nottlen M. 1995. Cryopreservation of porcine embryos. Nature 1995:374-416.

Parrish J.J., Susko-Parrish J.L. \& First N.L. 1988. Capacitation of bovine sperm by heparin. Biol. Reprod. 38:1171-1180.

Paschoal D.M., Sudano M.J., Guastali M.D., Maziero R.R.D., Crocomo L.F., Magalhães L.C.O., Rascado T.S., Martins Jr A. \& Landim-Alvarenga F.C. 2012. Forskolin effect on the cryosurvival of in vitro-produced bovine embryos in the presence or absence of fetal calf serum. Zygote 22:146-157.

Paschoal D.M., Sudano M.J., Maziero R.R.D., Guastali M.D., Magalhães L.C.O., Landim-Alvarenga F.C., Martins Jr A. \& Leal C.L.V. 2015. Decreased lipid granules of in vitro produced bovine embryos with low concentrations of forskolin. Anim. Reprod. 12:686.

Pereira R.M., Carvalhais I., Pimenta J., Baptista M.C., Vasques M.I., Horta A.E.M., Santos I.C., Marques M.R., Reis A., Silva Pereira M. \& Marques C.C. 2008. Biopsied and vitrified bovine embryos viability is improved by trans10, cis12 conjugated linoleic acid supplementation during in vitro embryo culture. Anim. Reprod. Sci. 106:322-332.

Perry G. 2015. 2013. Statistics of embryo collection and transfer in domestic farm animals. Embryo Transfer Newsletter 33:14-26.

Rizos D., Guitiérrez-Adán A., Pérez-Garnelo S., De La Fuente J., Boland M.P. \& Lonergan N.P. 2003. Bovine embryo culture in the presence or absence of serum: implications for blastocyst development, cryotolerance, and messenger RNA expression. Biol. Reprod. 68:236-243.

Rocha-Frigoni N.A.S., Leão B.C.S., Nogueira É., Accorsi M.F. \& Mingoti G.Z. 2014. Reduced levels of intracellular reactive oxygen species and apoptotic status are not correlated with increases in cryotolerance of bovine embryos produced in vitro in the presence of antioxidants. Reprod. Fertil. Dev. 26:797-805.

Sanches B.V., Marinho L.S.R., Oliveira Filho B.D., Pontes J.H.F., Basso A.C., Meirinhos M.L.G., Silva-Santos K.C., Ferreira C.R. \& Seneda M.M. 2013. Cryosurvival and pregnancy rates after exposure of IVF-derived Bos indicus embros to forskolin before vitrification. Theriogenology 80:372-377.

Sata R., Tsujii H., Abe H., Yamashita S. \& Hochi H. 1999. Fatty acid composition of bovine embryos cultured in serum-free and serum-containing médium during early embryonic development. J. Reprod. Develop. 45:97-103.

Seamon K.B., Padgett W. \& Daly J.W. 1981. Forskolin: unique diterpene activator of adenylate cyclase in membranes in intact cells. Proc. Natl Acad. Sci. USA 78:3363-3367.

Seidel Jr G.E. 2006. Modifying oocytes and embryos to improve their cryopreservation. Theriogenology 65:228-235.

Stein A. 2007. Decreasing variability in your cell culture. Biotechniques 43:228-229.

Stinshoff H., Wilkening S., Hanstedt A., Bollwein H. \& Wrenzycki C. 2014. Dimethylsulfoxide and conjugated linoleic acids affect bovine embryo development in vitro. Reprod. Fertil. Dev. 26(4):502-510.

Stringfellow D.A. 1998. Recommendations for the sanitary handling of in vivo derived embryos, p.79-84. In: Stringfellow D.A. \& Seidel S.M. (Eds), Manual of the International Embryo Transfer Society, Savoy, IL.

Vajta G., Rindom N., Peura T.T., Holm P., Greve T. \& Callesen H. 1999. The effect of media, serum and temperature on in vitro survival of bovine blastocysts after open pulled straw (OPS) vitrification. Theriogenology 52:939-948.

Wright J.M. 2009. Apêndice D: ilustrações fotográficas do estágio de desenvolvimento embrionário e códigos de qualidade, p.165-168. In: Ibid. (Ed.), Manual da Sociedade Internacional de Transferência de Embriões. $4 \underline{\underline{a}}$ ed. Savoy. 